\title{
INDEKS MODAL MANUSIA PENGUSAHA DAN PERANANNYA TERHADAP KINERJA USAHA KECIL
}

\author{
M. Farid Wajdi \\ Universitas Muhammadiyah Surakarta
}

\begin{abstract}
Penelitian ini bertujuan untuk membuat pengukuran modal manusia pengusaha kecil melalui penyusunan suatu indeks modal manusia (IMM). Modal manusia merupakan konsep yang tersusun dari berbagai aspek sumberdaya manusia. Aspek-aspek yang dimasukkan dalam indeks modal manusia ini terdiri dari aspek pendidikan, latihan, pengalaman, ketrampilan, dan kewirusahaan. Indeks yang disusun merupakan pengukuran akumulasi pencapaian kualitas sumberdaya manusia pengusaha. Dalam penyusunan indeks setiap aspeknya sudah dipastikan memiliki peranan terhadap kinerja usaha. Penelitian ini diharapkan memberikan pemahaman tentang bagaimana mengukur kemanfaatan investasi dalam peningkatan kualitas SDM sebagai suatu modal manusia yang akan bermanfaat dalam peningkatan kinerja usaha.
\end{abstract}

Kata Kunci:

Modal Manusia, Indeks Modal Manusia, Kesesuaian Latihan, Variasi Pengalaman, Ketrampilan, Kewirausahaan, Kinerja. 


\section{PENDAHULUAN}

Merujuk Djamaludin Ancok (2007) dalam tulisannya mengemukakan pandangannya tentang modal manusia, yang mengusulkan perlunya penelitian yang mencoba mengintegrasikan semua komponen secara utuh dalam diri manusia dan bagaimana dampaknya pada kinerja manusia (baik kerja individual, kerja tim dan kinerja organisasi) yang mana belum banyak dilakukan. Walaupun beberapa disertasi dan tesis master di bawah asuhan beliau telah mencoba melihat berbagai dampak dari modal manusia pada kinerja organisasi. Namun demikian, penelitian yang lebih intensif, khususnya dalam konteks kearifan lokal sangat perlu dilakukan supaya konsep modal manusia semakin teruji secara ilmiah dan cocok untuk diterapkan dalam budaya yang ada di Indonesia.

Sejalan dengan itu, sesuai dengan penelitian McGregor, dkk. (2004) yang menjelaskan pemikiran konsep modal manusia dengan mengaitkan pada model transisi hubungan untuk sebuah pekerjaan ekonomi baru. Dinyatakan bahwa perlunya memikirkan kembali berbagai kemampuan yang diperlukan oleh para manajer dan karyawan untuk kinerja usaha. Perkembangan teori dan penyusunan model harus dimasukkan berbagai faktor termasuk tipe SDM yang spesifik, isu keterampilan dan kemampuan, kepatuhan industri (industrial compliance), standar perilaku yang diperlukan oleh suatu pekerjaan modern, dan konsep keterampilan yang lebih sesuai. Singkatnya, modernisasi pekerjaan membutuhkan konsep baru melalui modal manusia.

Oleh karena itu perlu adanya kajian terpadu tentang berbagai aspek modal manusia terutama ketika dikaitkan dengan kinerja usaha. Dengan demikian penelitian tahun II ini akan menganalisis peranan aspek-aspek modal manusia yang disusun ke dalam Indeks Modal manusia pengusaha yang selanjutnya akan dianalisis bagaimanakah pengaruhnya terhadap kinerja usaha. Analisis penelitian akan menekankan dirumuskannya model indeks modal manusia yang perhitungannya paling sesuai dalam peningkatan kinerja usaha.

Tujuan penelitian ini adalah menyusun suatu pengukuran akumulasi aspek-aspek modal manusia yang dimiliki seseorang pengusaha yang dapat menunjukkan pencapaian kualitas modal manusia yang dapat berperan penting bagi kepentingan pengembangan kinerja usaha. Akumulasi kualitas modal manusia akan disusun dalam suatu indeks yang disebut sebagai Indeks Modal Manusia (IMM) pengusaha. Indeks Modal Manusia tersebut diharapkan secara signifikan mengukur secara akurat kualitas berbagai aspek yang dapat berkontribusi terhadap pembentukan modal manusia bagi pengusaha.

Modal manusia memiliki peran penting dalam penciptaan nilai ekonomi dan bisnis (McGregor dkk. 2004; Karami dkk. 2006). Modal manusia meliputi semua proses yang mampu memicu tingkat pengetahuan yang lebih tinggi dan melahirkan pengusaha yang kompetitif dan mampu menjalankan bisnis dengan lebih baik. Faktor kemampuan dan keterampilan modal manusia yang berkualitas diperlukan untuk meningkatkan kinerja perusahaan terutama dalam industri kecil dan menengah (Skuras 2005). Oleh karena itu, pembangunan manusia harus dilakukan agar kualitas manusia dapat ditingkatkan untuk kepentingan pembangunan ekonomi khususnya melalui peningkatan kualitas SDM industri.

Konsep modal manusia menurut pandangan modern mulai dipelopori oleh Schultz (1960) dan Becker (1964). Dalam perkembangannya, konsep modal manusia 
dapat dijelaskan sebagai kemampuan atau kapasitas baik sejak lahir atau keturunan maupun pengumpulan yang dibentuk selama usia bekerja secara produktif disertai dengan bentuk-bentuk modal atau input lain yang bertujuan untuk mencapai kemapanan ekonomi. Definisi lain menyebutkan secara lebih spesifik konsep modal manusia pada dasarnya adalah pendidikan atau intelektual, keterampilan dan pengalaman kerja (Yan dkk. 2003). Istilah modal manusia selanjutnya pada umumnya didefinisikan sebagai akumulasi pendidikan, termasuk pengetahuan dan keterampilan pada usia kerja yang terkumpul melalui pendidikan formal, pelatihan dan pengalaman.

Kajian tentang pencapaian kualitas SDM pengusaha mulai mendapat perhatian oleh pemerintah di berbagai negara. Seperti terjadi di Amerika Serikat dari penelitian Bates (2005) telah membuktikan bahwa meskipun industri kecil mendapat pemberian modal (kapitalisasi) yang besar saat memulai bisnis (start-up), namun tetap gagal karena diyakini akibat pengaruh pencapaian yang lebih rendah dalam pendidikan dan pengalaman spesifik bidang bisnis yang digeluti. Demikian juga pada industri kecil di Indonesia, berbagai bentuk bantuan modal dan insentif telah diberikan oleh pemerintah Indonesia, namun semuanya tidak memberikan hasil yang menggembirakan (Thee 2006).

Walaupun modal manusia telah diyakini memiliki peran penting bagi perekonomian dan bisnis namun berbagai penelitian gagal membuktikan signifikansinya. Sering ditemukan hasil penelitian modal manusia yang tidak signifikan (misalnya dalam kajian Pritchett 1997; Wayne et al. 1999; Pennings dkk. 1998; Dolton \& Vignoles 2000). Penelitian tersebut biasanya lebih berfokus pada penelitian bersifat modal manusia kuantitatif, yaitu aspek modal manusia yang diukur menggunakan ukuran seperti tahun dan tingkat pendidikan (Bruderl dkk. 1992; Cooper et al. 1994; Gimeno dkk. 1997) atau melalui jumlah tahun pengalaman bekerja (Evans \& Leighton 1989; Bruderl dkk. 1992). Sedangkan pengukuran secara kualitatif terhadap aspek modal manusia sering diabaikan dalam banyak studi yang telah dilakukan. Misalnya tidak memasukkan variasi pengalaman untuk mengukur pengalaman. Tidak memasukkan kualitas pelatihan atau kesesuaian latihan dalam mengukur pelatihan, serta tidak memperhatikan jenis keterampilan yang diperlukan ketika mengukur aspek keterampilan.

Perlu ditekankan bahwa aspek pengetahuan dan keterampilan yang bersifat kualitatif merupakan satu sumber yang penting bagi perusahaan untuk mempertimbangkan berbagai aspek modal manusia yang bersifat kualitatif. Misalnya untuk membedakan antara jenis keterampilan atau jenis pengalaman yang kemungkinan dapat lebih baik diketahui perannya terkait dengan kinerja. Selanjutnya dengan memasukkan aspek kualitas modal manusia yang diukur secara kualitatif, kemungkinan berbagai aspek modal manusia yang memiliki peran terhadap kinerja dapat dipahami dengan lebih baik untuk pembangunan kualitas SDM terutama bagi pengusaha.

Penelitian terdahulu tentang modal manusia kebanyakan hanya mencakup satu atau dua aspek saja secara terpisah. Begitu juga ketika menganalisis hubungannya dengan aspek kinerja, kebanyakan penelitian hanya mengkaji satu atau dua aspek kinerja saja dan seringkali menghasilkan signifikansi penelitian yang tidak pasti (Susanne, 2009; Clark, 2003; Hudson et al. 2001). Dimungkinkan hal itu disebabkan oleh tidak tepatnya penentuan keterkaitan antara aspek 
modal manusia yang dipilih, dan pengukuran setiap aspeknya.

Pemikiran ini sesuai dengan penelitian oleh McGregor dkk. (2004) yang menjelaskan kembali pemikiran tentang konsep modal manusia dengan mengaitkan pada model transisi hubungan pekerjaan untuk sebuah ekonomi baru. Dinyatakan bahwa perlunya memikirkan kembali berbagai kemampuan yang diperlukan oleh para manajer dan karyawan untuk kinerja suatu bisnis. Perkembangan teori dan penyusunan model harus dimasukkan berbagai faktor termasuk tipe sumber daya manusia yang khusus, isu keterampilan dan kemampuan, kepatuhan industri (industrial compliance), perilaku personel yang diperlukan oleh suatu pekerjaan modern, dan konsep keterampilan yang lebih sesuai. Singkatnya, modernisasi pekerjaan membutuhkan konsep baru melalui modal manusia.

Oleh karena itu perlu adanya kajian terpadu tentang berbagai aspek modal manusia terutama ketika dikaitkan dengan kinerja usaha. Hal ini dapat ditunjukkan dari penelitian yang menegaskan beberapa aspek modal manusia dalam menjelaskan beberapa aspek kinerja perusahaan (Bruderl dkk. 1992; Gimeno dkk. 1997; Pennings dkk. 1998; Pasanen 2003), dan termasuk pula dalam hal pertumbuhan dan survival perusahaan (Westhead 1995; McGregor dkk. 2004). Dengan demikian, penting membuat kajian empiris tentang berbagai aspek modal manusia yang mencakup aspek-aspek berbagai aspek modal manusia terutama aspek pendidikan, pelatihan, pengalaman, keterampilan, kewirausahaan dan jaringan.

Berdasarkan hasil dari penelitian Wajdi (20013), berbagai aspek yang memiliki pengaruh terhadap kinerja usaha kecil diantaranya adalah pendidikan, pelatihan, pengalaman, berbagai bentuk ketrampilan kerja, dan kewirausahaan.
Dengan terumuskannya modal manusia yang lebih komperhensif maka pengembangan sumber daya manusia dapat lebih efektif melalui pengembangan aspek masing-masing untuk meningkatkan kinerja usaha. Penyusunan indeks modal manusia (IMM) pengusaha yang dapat sebagai dasar untuk menilai kualitas pengusaha secara komperhensif dan untuk menyusun skenario pengembangan atau investasi pada modal manusia, selanjutnya. diharapkan dapat digunakan untuk pengembangan konsep modal manusia yang lebih komperhensif yang sesuai dengan kondisi Indonesia.

\section{TINJAUAN PUSTAKA}

Penelitian awal konsep modal manusia oleh Theodore Schultz, seorang pakar ekonomi empiris, dan pemenang Nobel, memulai kajian tentang sumber daya manusia ini sejak tahun 1960-an dan menekankan pentingnya investasi modal manusia dalam proses pembangunan. Dia telah menulis buku berjudul Transforming Traditional of Farm, terbit pada tahun 1964. Sebagaimana dicatat dalam Biography of Theodore William Schultz (1902-1998) bahwa dia telah menghadiri berbagai konferensi dan ketika mengunjungi ladang pertanian serta melakukan wawancara kepada petani hingga mendorong munculnya gagasan baru tentang modal manusia. Ia mempeloporinya bersama Gary Becker dan Jacob Mincer. Setelah perang dunia II, dalam catatannya melalui wawancara dengan seseorang petani tua yang bekerja dalam ladang pertanian miskin, namun mereka terlihat tetap bahagia. Sewaktu beliau menanyakan mengapa mereka tetap bergembira meskipun lemah dan miskin, mereka menjawab bahwa mereka tidak lemah atau miskin sebab mereka telah bekerja keras untuk mengirim empat anakanaknya ke perguruan tinggi dan anak-anak 
itu akan menjadi produktif karena pendidikan mereka. Schultz telah merumuskan konsep ini sebagai modal manusia, yaitu modal yang dihasilkan dengan berinvestasi dalam pengetahuan.

Menurut Becker pendidikan yang diterima di sekolah, pelatihan komputer, belanja kesehatan, pendidikan yang baik dan tepat waktu, serta kejujuran juga merupakan modal. Kondisi ini dapat dilihat bahwa seseorang itu akan lebih mudah untuk meningkatkan pendapatan dan kesehatan serta dapat menjamin kehidupan yang lebih baik. Oleh karena itu, pakar ekonomi telah bersepakat untuk memberi lebih memperhatikan biaya atas pendidikan, pelatihan dan kesehatan yang merupakan investasi penting untuk modal manusia. Ia dikatakan modal manusia adalah karena manusia tidak dapat dipisahkan dari pengetahuan, keterampilan dan kesehatan yang tidak ternilai dari uang dan asset fisik (The Concise Encyclopedia of Economics 2002).

Becker menambahkan bahwa pendidikan formal bukanlah merupakan satusatunya cara untuk investasi dalam modal manusia. Selain investasi dalam pendidikan, para pekerja juga harus belajar dan bergabung latihan melalui pelatihan di luar waktu bekerja terutama untuk pekerjaan yang tidak tetap. Hal ini karena di kebanyakan perguruan tinggi tidak menyediakan pelatihan tersebut kepada siswa saat mereka berada di perguruan tinggi. Oleh karena itu, untuk memasuki dunia kerja khususnya pekerjaan tidak tetap, calon tenaga kerja ini harus menghadiri program pelatihan secara formal maupun informal. Untuk beberapa pekerjaan telah tersedia latihan saat bekerja pada para karyawan. Namun jumlah pelatihan yang tersedia di tempat kerja adalah terbatas dari segi waktunya. Dengan demikian, pelatihan di luar waktu bekerja juga sangat diperlukan khususnya untuk memahami sesuatu pekerjaan yang rumit yang lebih membutuhkan waktu yang panjang.

Selain memiliki peranan penting dalam pembangunan suatu negara, modal manusia juga secara khususnya penting untuk kebutuhan produksi. Melalui penelitian Centre for the Study of Living Standard (2003) dinyatakan bahwa pembangunan dalam perspektif modal secara mudah dijelaskan dalam modal manusia, apakah dalam aspek pendidikan, keterampilan, maupun kesehatan. Tanpa berbagai keterampilan manusia tidak dapat berhasil memanfaatkan modal untuk produksi, dan menggunakan sumber-sumber alam untuk pembangunan ekonomi. Penelitian tersebut juga turut menyatakan bahwa pembangunan modal manusia dapat dilakukan secara formal dan informal. Modal manusia secara formal dapat diperoleh melalui pendidikan dan pelatihan sedangkan proses informal pula tersedia secara komprehensif yang diperoleh melalui pengalaman bekerja atau dengan melakukan sebuah bisnis.

Proses pembelajaran aktif bagi pengusaha dapat diperoleh melalui pengetahuan kognitif. Sedangkan proses non-kognitif merupakan pemupukan modal manusia yang diperoleh dan dikumpulkan secara spontan. Proses non-kognitif dapat dilihat melalui masa lampau pengusaha dan mungkin juga dapat dilihat pada lingkungannya. Misalnya, ia dapat dilihat dari latar belakang ibu atau bapaknya apakah merupakan pengusaha atau tidak, atau mungkin dapat dilihat pada sesuatu daerah atau tempat di mana ia dilahirkan dan dibesarkan. Proses formal dapat dianggap sebagai satu hal yang mendahului (antecendent) kepada kemampuan kewirausahaan. Sedangkan proses informal berupa tugas dan perilaku yang menghasilkan kemampuan-kemampuan 
kewirausahaan tersebut. Dengan demikian, proses pengumpulan modal manusia formal maupun informal sangat membantu pengusaha mencapai kemampuan dalam berbagai bidang seperti bidang keuangan, manajemen dan pemasaran.

Susanne (2009) dalam penelitian empirikalnya telah menganalisis hubungan antara modal manusia dan pertumbuhan ekonomi untuk mendapatkan penjelasan tentang kepentingan variabel modal manusia. Hasil penelitian yang diperoleh sejauh ini adalah hasil yang masih meragukan. Ia berpendapat bahwa temuan yang meragukan ini mungkin karena pengukuran modal manusia yang tidak tepat. Oleh karena itu, penelitiannya dilanjutkan untuk menganalisis bagaimana data modal manusia dikumpulkan dan diukur, serta apakah ia benar-benar mempengaruhi keputusan empiris antara modal manusia dan pertumbuhan ekonomi. Hasil proses investasi modal manusia dianalisis dalam bentuk model ekonometrik biner. Temuan penelitian menunjukkan bahwa modal manusia sangat penting untuk pertumbuhan ekonomi, namun penelitian tersebut telah menegaskan bahwa penemuan hasil penelitian adalah tergantung pada ketepatan pengukuran terhadap modal manusia.

Sedangkan terkait dengan kinerja perusahaan, ada beberapa penelitian yang menegaskan bahwa modal manusia merupakan faktor penting dalam menjelaskan kinerja perusahaan (Bruderl dkk. 1992; Gimeno dkk. 1997; Pennings dkk. 1998). Rahmah Ismail (2008) mencatat bahwa pembangunan sumber daya manusia terbukti penting dalam meningkatkan kinerja IKM. Kondisi ini telah dibuktikan melalui analisis terhadap data primer. Tabel silang dan pengujian ekonometrik yang dilakukan mampu menunjukkan hubungan yang signifikan antara beberapa variabel modal manusia dengan kinerja perusahaan. Oleh karena itu aspek pembangunan modal manusia harus diperkuat untuk meningkatkan pencapaian modal manusia dan akhirnya meningkatkan kinerja perusahaan. Pasanen (2003) melalui penelitiannya tentang kesuksesan bisnis menunjukkan bahwa pengusaha seharusnya menjamin bahwa perusahaan memiliki efisiensi yang cukup memadai. Pada satu sisi, pengusaha seharusnya memiliki pendidikan yang cukup dan pada sudut lain pula pengusaha harus juga memiliki pengalaman bekerja yang beragam khususnya dalam pemasaran dan produksi dan berbagai tugas manajemen. Hasil penelitian ini mendorong lebih lanjut untuk mengidentifikasi peran pendidikan dan berbagai pengalaman ke pada kinerja perusahaan dalam industri kecil.

Aspek pendidikan dipandang penting untuk para pengusaha baik pendidikan berbentuk ilmiah, teknologi dan seni liberal yang ada di perguruan tinggi yang mana dapat mendorong seseorang untuk berpikir secara terbuka dari apa yang mereka ketahui sebelumnya. Hal ini mengkaitkan 'pengetahuan praktis' dan 'pengetahuan ilmiah', dengan memberikan penekanan pada cara yang lebih baik yang mana para pengusaha lebih memanfaatkan peluang yang ada (Swedberg 2000).

Namun demikian, penelitian tentang kontribusi dari pengumpulan modal manusia terhadap pertumbuhan ekonomi sering memberikan hasil yang kurang meyakinkan. Meskipun pendidikan dipandang sebagai faktor terpenting dalam modal manusia, tetapi melalui penelitian terdahulu yang dilakukan sulit untuk memperoleh efek langsung hubungannya dengan kinerja bisnis. Seperti mana Clark (2003) melalui penelitian yang telah dilakukan menemukan hasil yang tidak konsisten terkait efek modal manusia pendidikan. 
Wijewardena dan Tibbits (1999) melalui penelitian mereka telah menjelaskan tentang tipe sumber daya manusia dan hubungannya dengan kinerja yang diukur dari kesuksesan atau pertumbuhan perusahaan. Aspek-aspek tersebut jika dirumuskan dalam terminologi konsep modal manusia dapat lebih ringkas, yaitu pengalaman, keterampilan, pendidikan, jaringan, pelatihan, dan kewirausahaan. Aspek pengalaman mencakup tipe pengalaman kewirausahaan ibu-bapak pengusaha, pengalaman yang luas, pengalaman memulai bisnis, pengalaman berusaha, pengalaman dalam manajemen dan kewirausahaan, pengalaman melakukan bisnis yang sama, dan pengalaman sebagai pemilik. Aspek keterampilan mencakup tipe kemampuan untuk memuaskan pelanggan, bisa mendapatkan target pasar (market niche), memberi layanan yang bagus, tim manajemen yang bagus, berpengetahuan praktis (know how), kemampuan mengelola, kemampuan melakukan tugas, kemampuan dapat berhubungan secara baik dengan klien. Aspek pendidikan mencakup aspek-aspek pendidikan pemilik dan pengetahuan pemilik. Aspek jaringan mencakup aspekaspek seperti memiliki jaringan kerja yang bagus dan menjadi anggota kelompok industri. Aspek pelatihan pula meliputi pelatihan yang pernah diterimanya. Sedangkan aspek kewirausahaan mencakup kreativitas, dan pengalaman kewirausahaan.

Pelatihan merupakan salah satu faktor penting sebagai elemen pada pembangunan sumber manusia. Pelatihan merupakan pelengkap kepada pendidikan. Menurut Taylor dan Plummer (2003) menyatakan bahwa hanya dengan pendidikan saja tidak mampu untuk menjalani hidup seseorang. Kondisi ini menunjukkan bahwa pendidikan tidak memberikan individu dengan kemampuan untuk memahami aspek ekonomi dan masyarakat di mana mereka tinggal dan proses perubahan yang ada disekelilingnya (Hudson et al. 2001). Latihan dapat lebih berkonsentrasi pada usaha memperoleh sumber daya manusia dengan keterampilan khusus atau membantu seseorang memperbaiki kekurangannya dalam pencapaian pretasi dirinya (Gomez dkk. 1998). Oleh karena itu disamping aspek pendidikan perlu adanya pelatihan sebagai tambahan kepada aspek modal manusia.

Pengalaman kerja merupakan satu dari aspek sering digunakan dalam mengukur modal manusia. Pengalaman kerja adalah merupakan pengetahuan atau kemampuan kerja yang diperoleh oleh seseorang karena melakukan pekerjaan dalam jangka waktu tertentu (Depnakertrans 2006). Pengalaman kerja biasanya dibedakan melalui waktu kerja. Oleh karena itu, pengalaman kerja pengusaha tidak hanya diukur dari waktu kerja, tetapi perlu juga dikaji tentang jumlah pengalaman yang ada. Hal ini karena jumlah pengalaman bukan berarti kualitas lebih tinggi, tetapi apa saja pengetahuan atau kemampuan yang diperoleh dalam periode seseorang itu berada dalam alam pekerjaan (Aaker 1984).

Dengan demikian dapat difahami arti penting pengalaman bekerja atau pengalaman mengelola perusahaan secara umum berperan terhadap kinerja bisnis (Ardichvili dkk. 2003; Davidsson \& Honig 2003). Hal ini menyebabkan para peneliti menyarankan bahwa meneruskan pengalaman pengusaha yang sebelumnya atau yang ada saat ini akan sangat berguna untuk meningkatkan manfaat pembelajaran kewirausahaan untuk pengusaha baru (Cope \& Watts 2000; O'Sullivan 2000). Oleh karena itu, adalah penting untuk kita mengidentifikasi bentuk pengalaman yang berperan atas kinerja industri kecil.

Penelitian Martin dan Staines (1994) yang menganalisis tentang manajemen perusahaan kecil menyatakan bahwa dari 
data kuesioner menunjukkan bahwa manajer perusahaan kecil harus memiliki ketrampilan teknis yang komprehensif dalam industri mereka. Analisis faktor menunjukkan perbedaan terhadap kepentingan relatif yaitu keterampilan teknis dan keterampilan manajemen yang mana keterampilan teknis yang baik adalah merupakan faktor terpenting dalam menjalankan perusahaan kecil yang berhasil. Data dari penelitian ini menegaskan pentingnya melaksanakan beberapa ketrampilan pribadi untuk perusahaan kecil.

Kemampuan atau ketrampilan yang ada pada karyawan akan membawa kepada perlunya berbagai keterampilan yang berperan penting untuk pembangunan modal manusia pengusaha industri kecil. McLeish (2002), Smith dan Comyn (2003) telah melakukan pengembangan employability skill. Istilah employability skill (keterampilan kerja) ini berdasarkan pada hasil penelitian proyek bersama di antara Departemen Pendidikan, Sains dan Pelatihan, Commonwealth of Australia, dan The Australian National pelatihan Authority (ANTA) yang dilaksanakan dan telah dilaporkan dalam Business Council of ACCI (McLeish 2002 ; Smith \& Comyn 2003). Aspek keterampilan kerja tersebut terdiri dari keterampilan berhubungan dengan orang lain (Interpersonal Skills), keterampilan inisiatif dan berbisnis (Initiative dan Enterpsise Skills), keterampilan belajar (Learning Skills) dan keterampilan menerapkan kerja (Workplace Skills). Namun, untuk mempelajari semua aspek tersebut harus disertakan dengan berbagai komponen dan indikator lain. Semua aspek tersebut merupakan aspek keterampilan yang masih baru dan dikenal sebagai employability for the future oleh ACCI. Keterampilan tersebut diyakini memiliki kesesuaian dalam pembangunan modal manusia pengusaha industri kecil. Saat ini, masih belum ditemukan aspek tersebut dipakai sebagai dasar penelitian modal manusia.

Sedangkan aspek Kewirausahaan terpercaya mampu memiliki implikasi positif yang universal atas kinerja. Hyrsky (2000) dalam penelitian tentang analisis faktor pada keragaman cabang kewirausahaan untuk kaum pengusaha dan manajer industri kecil di Eropa, Amerika Utara, Austria, dan Australia menunjukkan bahwa bidang kewirausahaan adalah memiliki potensi, komitmen dan keyakinan pada pekerjaan, memiliki nilai-nilai ekonomi dan keluaran, resiko, inovatif dan berprestasi.

Dari catatan Wijewardena dan Tibbits tersebut mendorong untuk membuat kajian empiris tentang berbagai aspek modal manusia yang mencakup berbagai aspek. Aspek-aspek berbagai aspek modal manusia tersebut didukung dengan berbagai peneliti lain dapat dirumuskan diantaranya meliputi aspek pendidikan, pelatihan, pengalaman, keterampilan, kewirausahaan dan jaringan.

Dari berbagai kajian yang ada dapat dilihat bahwa terdapat berbagai aspek-aspek sumber daya manusia yang dapat diringkas ke dalam konsep modal manusia, diantaranya adalah pengalaman, keterampilan, pendidikan, jaringan, pelatihan dan kewirausahaan. Pengumpulan modal manusia bertujuan untuk mendorong kreativitas, rasa ingin tahu, berpikiran terbuka dan keterampilan, yang semua ini memberikan kontribusi terhadap inovasi dan peningkatan kinerja.

Namun demikian, kebanyakan penelitian yang lalu menunjukkan bahwa hubungan modal manusia dengan kinerja adalah tidak signifikan yang mana penelitian tersebut biasanya lebih terkonsentrasi pada sifat kuantitatif modal manusia. Sebaliknya, penelitian-penelitian yang dilakukan juga harus mempertimbangkan pada aspek modal manusia yang bersifat kualitatif seperti 
pengalaman, keterampilan dan kewirausahaan.

\section{METODE PENELITIAN}

Penelitian ini dilakukan pada unit usaha yang termasuk kategori industry kecil menengah (IKM). Lokasi penelitian mengambil beberapa kabupaten/kota di sekitar Solo raya. Pengambilan sampel dilakukan dengan menggunakan cluster sampling, yaitu penelitian dilakukan pada kabupaten/kota yang terdapat banyak unit industri kecilnya dibanding daerah lainnya., yaitu Surakarta, Klaten, Sukoharjo, Boyolali, Sragen. Responden dalam penelitian ini adalah pengusaha, pemilik atau manajer perusahaan kecil. Sampel unit direncanakan sebanyak 400 unit perusahaan kecil, namun dari hasil pengumpulan data akhirnya diperoleh sebanyak 356 responden.

$$
\text { Untuk menentukan sampel }
$$

pengusaha dan perusahaan digunakan purposive sampling, yaitu yang memiliki kriteria sebagai berikut:

- Produk utamanya tergolong dalam jenis sektor manufaktur.

- Telah beroperasi setidaknya sudah lebih dari lima tahun.
- Pengusaha pernah mengikuti latihan minimum satu kali dalam salahsatu jenis latihan.

Untuk memperoleh data primer menggunakan metode survei, dengan menggunakan wawancara berpedoman kuesioner. Untuk meningkatkan isi dan makna dari instrumen survei, dilakukan uji validitas dan uji reliabilitas. Sedangkan untuk menganalisis pengaruh variabel aspekaspek modal manusia dan variabel terhadap kinerja kecil analisis regresi menggunakan regresi linear biasa (OLS). Secara umum model regresi impak aspek modal manusia terhadap prestasi (Pi) dapat dituliskan persamaannya sebagai berikut.

$$
P_{i k}=\alpha_{k}+\beta I M M+e_{k}
$$

Dengan keterangan:

$P \quad$ adalah variabel kinerja (Penjualan, Kualitas Produk, Kepuasan Pelanggan)

IMM adalah Indeks modal manusia

$\alpha, \beta$, adalah parameter

$i \quad$ adalah individu pengusaha

$k \quad$ adalah jenis variabel dependen

$e \quad$ adalah eror

Pada Tabel 1. berikut dijelaskan definisi operasional variabel dan pengukurannya.

Tabel 1.

Definisi Operasional Variabel dan Pengukurannya

\begin{tabular}{|r||l||l||}
\hline \multicolumn{1}{|c||}{ No } & \multicolumn{1}{|c|}{ Variabel } & \multicolumn{1}{c|}{ Definisi } \\
\hline \hline 1 & Pendidikan & $\begin{array}{l}\text { Lama tahun pengusaha dalam mengikuti pendidikan formal (Gimeno et al. } \\
1997 \text { Pennings et al. 1998). }\end{array}$ \\
\hline \hline 2 & Kesesuaian Latihan & $\begin{array}{l}\text { Penilaian pengusaha atas kesesuaian latihan dengan keperluan bisnesnya, } \\
\text { meliputi kesesuaian materi, metode, kompetensi mentor, fasilitas latihan. } \\
\text { (Huang, 2001; Dessler,2003; Jack J,2000) Penilaian mengguna skala Likert, } \\
\text { yaitu : 1=sangat kurang, 2=kurang, 3=cukup, 4=bagus,5= sangat bagus. }\end{array}$ \\
\hline \hline 3 & Jumlah Latihan & Jumlah latihan yang pernah diikuti pengusaha. \\
\hline \hline 4 & Lama Pengalaman & $\begin{array}{l}\text { Lama tahun pengusaha menjalani pekerjaan sebagai pengusaha hingga } \\
\text { sekarang. }\end{array}$ \\
\hline \hline 5 & Pengalaman lengkap & $\begin{array}{l}\text { Lengkapnya pengalaman pengusaha menggeluti pekerjaan berbagai bidang } \\
\text { pengurusan perniagaan pada masa lepas (Cope dan Watts, 2000; Sullivan, } \\
\text { 2000), yaitu pekerjaan bidang pemasaran, operasi, kuangan. Pengukuran } \\
\text { secara dami. }\end{array}$ \\
\hline
\end{tabular}




\begin{tabular}{|c|c|c|}
\hline 6 & $\begin{array}{l}\text { Keterampilan } \\
\text { Interpersonal } \\
\text { (Interpersonal Skill) }\end{array}$ & $\begin{array}{l}\text { Ketrampilan berkomunikasi dengan sebarang orang (pelanggan) dan bekerja } \\
\text { tim dengan karyawan yang berperan untuk hubungan harmonis dan produktif } \\
\text { (McLeish, 2002; Smith, 2003). Penilaian menggunakan skala Likert, yaitu : } \\
\text { 1=sangat kurang, 2= kurang, 3=cukup, 4=bagus, 5=sangat bagus. }\end{array}$ \\
\hline 7 & $\begin{array}{l}\text { Keterampilan Kerja } \\
\text { Operasional } \\
\text { (Workplace Skill) }\end{array}$ & $\begin{array}{l}\text { Ketrampilan menggunakan teknologi yang berperan untuk pengamalan } \\
\text { pekerjaan secara berkesan (McLeish, 2002; Smith, 2003). Penilaian } \\
\text { menggunakan skala Likert, yaitu : 1=Sangat Kurang, 2= Kurang, 3=cukup, } \\
\text { 4= Bagus, 5=Sangat Bagus. }\end{array}$ \\
\hline 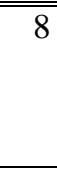 & Kewirausahaan & $\begin{array}{l}\text { Sikap pengusaha dalam inovasi, proaktif dan mengurus risiko untuk } \\
\text { mengembangkan usahanya (Waltera, et al. 2005, Covin dan Slevin, 1991). } \\
\text { Penilaian menggunakan skala Likert, yaitu : 1=Sangat Kurang, 2= Kurang, } \\
\text { 3=cukup, 4= Bagus, 5=Sangat Bagus. }\end{array}$ \\
\hline 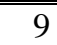 & Penjualan & "Rata-rata bulanan hasil penjualan dalam uang selama satu tahun. \\
\hline 10 & Kualitas Produk & $\begin{array}{l}\text { Kesesuaian produk yang dihasilkan dengan spesifikasi produk yang } \\
\text { dipersyaratkan pembeli (Maes, 2003). Diukur prosentase produk yang sesuai } \\
\text { persyaratan pembeli dari keseluruhan produk yang dikeluarkan setiap bulan. }\end{array}$ \\
\hline 11 & Kepuasan Pelanggan & $\begin{array}{l}\text { Proxy daripada penilaian pengusaha tentang keluhan pelanggan setiap } \\
\text { bulannya mengenai kesesuaian produk, ketersediaan produk, ketepatan } \\
\text { waktu penyelesaian, kesempurnaan produk, dan pelayananannya (Riley Jr., } \\
\text { et al. 2003) Penilaian menggunakan skala Likert, yaitu: 1=selalu ada, } \\
\text { 2=sering, 3=kadang-kadang, 4=jarang, 5=tidak pernah. }\end{array}$ \\
\hline
\end{tabular}

\section{METODE ANALISA DATA}

Sedangkan model analisis dilakukan untuk pembentukan indeks modal manusia (IMM) bagi para pengusaha. Untuk pembentukan Indeks Modal Manusia maka berikutnya dari semua aspek modal manusia dikompilasi. Untuk menyusun indeks nilai manusia modal pengukuran hasil setiap aspek modal manusia dan kemudian dinormalisasi dengan menggunakan rumus berikut:

Normalisasi $M M_{j}=\sum_{i=1}^{n} \frac{N M M_{i}-\min }{m a k-\min }$ dengan keterangan:

MM adalah variabel modal manusia

NMM adalah nilai dari variabel modal manusia

min adalah nilai minimum dari variabel modal manusia

max adalah nilai maksimum dari variabel modal manusia

i adalah individu / pengusaha j adalah jenis variabel modal manusia

Langkah selanjutnya adalah menentukan bobot setiap aspek modal manusia. Hasil perhitungan normalisasi setiap aspek modal manusia kemudian dibuat beban. Penentuan skala diberi bobot berdasarkan peran penting mereka dalam membentuk aspek kualitas modal manusia.

Bobot setiap aspek modal manusia didasarkan pada gagasan bahwa pendidikan dan pelatihan merupakan aspek penting bagi para pengusaha yang terkait dengan pengetahuan, keterampilan, motivasi, kepercayaan diri dan kemampuan untuk memberikan jangka pendek masalah solusi bisnis dan jangka panjang (Lundvall dan Johnson, 1994). Kemudian, menurut konsep modal manusia dari Schultz dan Becker tentang pentingnya pendidikan, maka pendidikan merupakan faktor kunci dalam modal manusia, sehingga pendidikan memiliki 0,25 tertimbang tertinggi. Kursus pelatihan mungkin telah ditimbang aspek 
Bearan pendidikan yang sama, tetapi untuk pengusaha dengan pelatihan, umumnya tidak kompatibel dengan kebutuhan industri kecil (Tambunan, 2000) kemudian skor lebih kecil dari pendidikan. Berikutnya pelatihan, pengalaman, dan keterampilan merupakan aspek yang telah banyak digunakan dalam mengukur modal manusia, maka ketiga aspek diberi bobot yang sama dari 0,2.
Kewirausahaan sebagai faktor dalam motivasi diri merupakan aspek pendukung pengusaha bagi pengusaha untuk menjadi tindakan berani untuk meningkatkan operasi perusahaan untuk mencapai keberhasilan. Namun, peran kewirausahaan lebih kecil di bawah aspek sebelumnya, diberi bobot 0,1. Berdasarkan alasan pemikiran di atas, bobot setiap aspek modal manusia dapat dilihat sebagai dalam Tabel 2. di bawah ini.

Tabel 2.

Bobot Indeks Modal Manusia

\begin{tabular}{|l||l|l|}
\hline Modal Manusia & $\begin{array}{c}\text { Bobot Aspek Modal } \\
\text { Manusia }\end{array}$ & Bobot Variabel \\
\hline \hline 1.Pendidikan & 0.2 & 0.2 \\
\hline \hline 2.Latihan & $0.2,5$ & \\
\hline \hline 2.1. Kesesuaian Latihan & & 0.125 \\
\hline 2.2. Jumlah Latihan & $0.2,5$ & 0.125 \\
\hline \hline 3.Pengalaman & & 0.125 \\
\hline 3.1. Lama Pengalaman & & 0.125 \\
\hline 3.2. Lengkapnya Pengalaman & 0.2 & \\
\hline 4.Ketrampilan & & 0.1 \\
\hline 4.1. Interpersonal & & 0.1 \\
\hline \hline 4.2. Kerja operasional & 0.1 & 0.1 \\
\hline 5.Kewirausahaan & 1.0 & 1.0 \\
\hline \hline Jumlah &
\end{tabular}

Selanjutnya indeks modal manusia diperoleh dengan menggunakan rumus sebagai berikut :

$$
I M M=\sum_{j=1}^{m} W_{j} M M_{j}
$$

Dengan keterangan :

IMM adalah indeks modal manusia

$W_{j} \quad$ adalah bobot

MM adalah variabel modal manusia

\section{HASIL DAN PEMBAHASAN}

\subsection{Indeks Modal Manusia Pengusaha}

Pengusaha dalam penelitian ini dilihat dari usia paling banyak (48\%) berusia antara 41 sampai 50 tahun, pendidikan pengusaha sebagian besar (40,4\%) berpendidikan SMA, kemudian lama pengalaman pengusaha kebanyakan $(50,4 \%)$ berpengalaman 11 sampai 20 tahun, sedangkan dilihat pengalaman lengkap kebanyakan (61\%) berpengalaman lengkap dalam dua dari tiga bidang manajemen bisnis, yaitu antara bidang produksi, pemasaran, dan keuangan. 
Sedangkan dari aspek pelatihan pada setiap jenis latihan kebanyakan pengusaha (antara 44\% sampai 56\%) pernah bergabung satu sampai tiga kali latihan. Dilihat kesesuaian pelatihan dengan kebutuhan bisnisnya, kebanyakan pengusaha (49\%) menyatakan bahwa pelatihan yang pernah diikuti "cukup sesuai" dengan kebutuhan bisnisnya, meskipun banyak juga pengusaha yang menyatakan kurang sesuai yaitu sebesar $42.6 \%$, dan hanya sebesar $8,4 \%$ yang menyatakan "bagus" kesesuaian pelatihan yang pernah diikutinya.

Dalam aspek keterampilan dari semua aspek keterampilan sebagian besar pengusaha memiliki keterampilan "cukup", demikian juga dalam aspek kewirausahaan sebagian besar juga dalam kategori "cukup". Kemudian dilihat dari kepemilikan jaringan ada distribusi yang hampir sama jumlahnya antara pengusaha yang tidak memiliki jaringan (28\%), memiliki satu hingga tiga (33\%), dan memiliki empat sampai enam jaringan (30\%).
Dari pencapaian berbagai aspek modal manusia yang telah dibahas. Selanjutnya disusun indeks modal manusia yang menunjukkan pencapaian modal manusia pengusaha secara keseluruhan aspek. Penyusunan indeks modal manusia pengusaha menggunakan rumus di atas. Hasil pengukuran setiap aspek modal manusia dilakukan normalisasi untuk setiap aspek kemudian ditentukan bobot dimana setiap aspek modal manusia berdasarkan peran setiap aspek dalam menentukan kualitas sumber daya manusia pengusaha (lihat rumusan 4.17). Aspek pendidikan memiliki bobot paling tinggi yaitu 0,25, kemudian aspek pelatihan, pengalaman, dan keterampilan, ketiganya diberi bobot yang sama sebesar 0,2, sedangkan kewirausahaan diberi bobot 0.1, dan jaringan diberi bobot terendah, yaitu 0,05. Hasil dari perhitungan indeks modal manusia dapat dilihat pada Tabel 3. di bawah ini.

Tabel 3.

Pencapaian Indeks Modal Manusia Pengusaha

\begin{tabular}{||c|r|r||c||}
\hline \multicolumn{1}{|c|}{ Kelas } & Jumlah Pengusaha & \multicolumn{1}{|c|}{ Persentase } & Kategori \\
\hline \hline $0,00-0,25$ & 16 & 4,5 & Rendah \\
\hline $0,26-0,50$ & 139 & 38,7 & Sedang \\
\hline \hline $0,51-0,75$ & 134 & 37,3 & Cukup \\
\hline $0,76-1,00$ & 70 & 19,5 & Tinggi \\
\hline \hline Jumlah & 359 & 100 & \\
\hline
\end{tabular}

Sumber : analisis data

Dari Tabel 3. di atas terlihat secara umumnya pencapaian indeks modal manusia usahawan berada pada kategori "sedang" dengan skor indeks antara 0.26 - 0.50 iaitu sebanyak $38.7 \%$. Pencapaian terbanyak pada kategori "sedang" ini sewajarnya, kerana meskipun pencapaian pendidikan usahawan terbanyak pada peringkat SMA atau "cukup tinggi”, pengalaman lengkap, berbagai jenis kemahiran, dan keusahawanan juga cukup bagus, tetapi daripada setiap jenis latihan, lama pengalaman, kebanyakannya adalah rendah. Oleh karena itu ketika semua aspek modal manusia digabung dalam sebuah indeks maka pencapaian kebanyakan usahawan sewajarnya hanya pada kategori "sedang" saja.

Sedangkan sebaran indeks modal manusia usahawan dihuraikan sebagai berikut. Sebanyak $4.5 \%$ usahawan 
pencapaian indeks modal manusianya dalam kategori "rendah", dengan skor antara sifar hingga 0.25 . Pencapaian indeks modal manusia usahawan paling banyak terlihat berada pada kelas antara 0.26 hingga 0.50 termasuk dalam kategori "rendah", iaitu sebanyak 139 atau $38.7 \%$ usahawan. Kemudian dalam sebaran yang hampir sama banyaknya iaitu 134 atau 37.3\% usahawan memiliki skor indeks modal manusia antara 0.51 hingga 0.75 , termasuk dalam kategori “cukup”. Manakala pencapaian indeks modal manusia dalam kategori "tinggi” dengan skor indeks diatas 0.75 terlihat sebanyak 70 usahawan atau $19.5 \%$.

\subsection{Analisis Pengaruh Indeks Modal Manusia Terhadap Kinerja}

Selanjutnya dalam bagian ini diuraikan hasil tes estimasi indeks modal manusia pada aspek kinerja dan indeks prestasi. Indeks modal manusia adalah komposit berbagai aspek modal manusia yang menunjukkan pencapaian modal manusia pengusaha secara keseluruhan. Keputusan estimasi regresi pada setiap aspek kinerja dapat dijelaskan sebagai berikut.

\subsubsection{Peranan Indeks Modal Manusia terhadap Penjualan \\ Berdasarkan hasil regresi pada Tabel} 4. ditemukan bahwa akurasi model persamaan (goodness of fit) adalah sangat baik yaitu berdasarkan tes t-statistik yang signifikan, nilai R2 yang tinggi serta tes-F yang signifikan pada level 1\%. Penjualan sebagai variabel dependen dalam bentuk logaritma natural (ln) namun demikian konstanta estimasi sudah dibuat antilog. Dari hasil analisis dapat dilihat bahwa setiap kenaikan pencapaian indek modal manusia pengusaha akan dapat meningkatkan kinerja penjualan sebesar 16,8\%. Dengan demikian peningkatan indeks modal manusia dapat berperanan dalam peningkatan kinerja penjualan usaha kecil.

Tabel 4.

Hasil Regresi Indeks Modal Manusia terhadap Penjualan

\begin{tabular}{||l||r||c||}
\hline \multicolumn{1}{|c||}{ Variabel } & & $\beta$ \\
\hline \hline Konstata & 1.009 & $(0.248)$ \\
\hline \hline Indeks Modal Manusia & 16.883 & $(11.738)^{* * *}$ \\
\hline \hline R2 & & 0.278 \\
\hline \hline Adjusted R2 & & 0.276 \\
\hline \hline Uji F & & $137.786^{* * *}$ \\
\hline \hline$* * *$ signifikan pada signifikansi $\alpha 1 \%$. & \multicolumn{2}{|c||}{} \\
\hline
\end{tabular}

\subsubsection{Peranan Indeks Modal Manusia terhadap Kinerja Kualitas Produk}

Selanjutnya dianalisis peran indeks modal manusia terhadap kenerja kualitas produk. Dari hasil regresi (Tabel 5.) ditemukan bahwa akurasi model (goodness of fit) estimasi menunjukkan cukup baik. Sama seperti estimasi sebelumnya, efek indeks modal manusia terlihat positif dan signifikan bagi semua estimasi pada tingkat signifikansi $1 \%$. Ini berarti setiap kenaikan satu titik indeks modal manusia pengusaha akan meningkatkan pencapaian kualitas di antara sampai $28,5 \%$ dari jumlah produksi perusahaan. Peran indeks modal manusia dapat meningkatkan kualitas produk. 
Tabel 5.

Hasil Regresi Modal Manusia terhadap Kualitas Produk

\begin{tabular}{|l||r||c||}
\hline \multicolumn{1}{|c||}{ Variabel } & & $\beta$ \\
\hline \hline Konstata & 61.258 & $(33.485)^{* * *}$ \\
\hline \hline Indeks Modal Manusia & 28.552 & $(9.945)^{* * *}$ \\
\hline \hline R2 & & 0.217 \\
\hline \hline Adjusted R2 & & 0.215 \\
\hline \hline Uji F & & $98.911^{* * *}$ \\
\hline \hline$* * *$ signifikan pada aras signifikansi $1 \%$. & \\
\hline
\end{tabular}

\subsubsection{Peranan Indeks Modal Manusia terhadap Kepuasan Pelanggan}

Berdasarkan Tabel 6. hasil penelitian menunjukkan efek indeks modal manusia terhadap kepuasan pelanggan. Hasil regresi menemukan bahwa akurasi model (goodness of fit) estimasi menunjukkan hasil yang sangat baik. Sama seperti keputusan aspek lain, indeks modal manusia pengusaha memiliki dampak positif dan signifikan pada tingkat 1\%. Kondisi ini berarti bahwa pengusaha yang memiliki pencapaian modal manusia lebih tinggi mampu untuk memberikan kepuasan yang lebih tinggi kepada pelanggan. Dengan demikian, peran indeks modal modal manusia terbukti dapat meningkatkan kinerja kepuasan pelanggan.

Tabel 6.

Hasil Regresi Modal Manusia terhadap Kepuasan Pelanggan

\begin{tabular}{|l||r||c||}
\hline \multicolumn{1}{|c||}{ Variabel } & & \multicolumn{1}{c||}{$\beta$} \\
\hline \hline Konstata & 3.001 & $(3.132)^{* * *}$ \\
\hline \hline Indeks Modal Manusia & 16.977 & $(11.288)^{* * *}$ \\
\hline \hline R2 & & $(0.263)$ \\
\hline \hline Adjusted R2 & & $(0.261)$ \\
\hline \hline Uji F & & $(27.428)^{* * *}$ \\
\hline \hline$* * *$ signifikan pada aras signifikansi $1 \%$. & \\
\hline
\end{tabular}

\section{PENUTUP}

Dari hasil analisis dan perhitungan indeks modal manusia maka dapat disimpulkan bahwa pencapaian indeks modal manusia pengusaha umumnya pencapaian pengusaha berada pada kategori "rendah" dan "cukup" saja, antara kedua distribusi jumlah usahawannya hampir sama banyaknya, yaitu sebesar 38,7\% dan 37,3\%. Dengan demikian secara keseluruhan kualitas modal manusia pengusaha kecil dilihat dari aspek pendidikan, pelatihan, pengalaman, kemahiran, kewirausahaan dan kepemilikan jaringan masisih perlu ditingkatkan.

Dari hasil analisis dapat dilihat bahwa setiap kenaikan pencapaian indek modal manusia pengusaha akan dapat meningkatkan kinerja penjualan sebesar 16,8\%. Dengan demikian peningkatan indeks modal manusia dapat berperanan dalam peningkatan kinerja penjualan usaha kecil. Peranan indeks modal manusia terhadap kualitas produk terlihat positif dan signifikan bagi pada tingkat signifikansi $1 \%$, artinya peran indeks modal manusia dapat meningkatkan kualitas produk. Sedangkan pengusaha yang memiliki pencapaian modal 
Indeks Modal Manusia... (M. Farid Wajdi)

manusia lebih tinggi mampu untuk memberikan kepuasan yang lebih tinggi kepada pelanggan. Dengan demikian, peran indeks modal modal manusia terbukti dapat meningkatkan kinerja kepuasan pelanggan. 


\section{DAFTAR PUSTAKA}

Aaker,David.1984.Developing business strategies, N.Y.:,JohnWiley \& Sons.

Aquilina, Matteo., Klump, Rainer., Pietrobelli, Carlo. 2006. "Factor substitution, average firm size and economic growth”,Springer 2006 DOI10.1007/S11187-005-4715-4. Small Business Economics(26): 203-214

Ardichivili, A., Cardozo, R., \& Sourav, R. 2003. “A theory of entrepreneurial opportunity identification and development”.Journal of Business Venturing, 18(1): 105-123.

Atherton, Andrew. 2005.A future for small business? Prospective scenarios for the development of the economy based on current policy thinking and counterfactual reasoning futures, Available online 19 March 2005, 37: 777-794. www.elsevier.com/locate/futures. [15 April 2006]

Barney, J. 1991.” Firm resources and sustained competitive advantage”. Journal of Management, (17): 99120.

Barro, Robert J., Sala-i-Martin. 1995. “Technological Diffusion, Convergence, and Growth, Economics Working Paper” 116, Journal of Economic Literature classification: O40, E10, http://www.econ.upf.edu/docs/papers/ downloads/116.pdf.[2 Mac 2006].

Bates, Timothy. 1990. "Entrepreneur human capital inputs and small business longevity”. The Review of Economics and Statistics, (72): 551-559.

Bates, Timothy. 2005. "Analysis of young, small firms that have closed: Delineating successful from unsuccessful closures”, Wayne State University, Detroit, Mi 48202, USA Journal of Business Venturing (20):343-358.

Becker, Gary S. 1975. Human Capital: A Theoretical and Empirical Analysis, with Special Reference to Education, 2 ${ }^{\text {nd }}$, The University of Chicago Press, NBER, ISBN: 0-226-04109-3, http://www.nber.org/books/beck75-1. [2 Mac 2006].

Bruderl, J., Prusendorfer, P., Zeigler, R. 1992. „Survival chances of newly founded business organizations”. American Sociological Review. 57 (2): 227-241.

Chandler, G., Hanks, S., 1991. Howimportant is experience in a highly similar field? Frontiers of Entrepreneurship Research, Proceedings of the 11th Annual Babson College Entrepreneurship Research Conference. Babson College, Wellesley, MA: 1-10.

Clark, Andrew, 2003, "Returns to human capital investment in a transition economy the case of Russia”, 1994-1998, International Journal of Manpower, 24(1): 11-30.

Cooper, A.C., Gimeno-Gascon, F.J. \& Woo, C.Y. 1994. "Initial human and financial capital as predictors of new venture performance”.Journal of Business Venturing, (9): 371- 395.

Cooper, A.C., Gimeno-Gascon, F.J.1992.Entrepreneurs, processes of founding and new firm performance. In: Sexton, D.L., Kasarda, J.D. (Eds.), The State of the Art of Entrepreneurship. PWS-Kent,Boston,

Cope, Jason; Watts, Gerald.2000. Learning by doing - An exploration of experience, critical incidents and reflection in entrepreneurial learning.International Journal of Entrepreneurial Behaviour and Research,Publisher: Emerald Group Publishing Limited, 6( 3): 104-124.

Davidsson, Per., Kirchhoff, Bruce., Hatemi-J, Abdulnasser., Gustavsson, Helena. 2000. Factors Underlying Business Growth In Sweden, Jonkoping International Business School Jonkoping, Sweden, Presented at ICSB World Conference June 7-10, 2000, Brisbane, Australia.

DEPNAKERTRANS. 2006. Data dan informasi ketenagakerjaan; ragam data, informasi dan publikasi ketenagakerjaan; penganggur terbuka menurut pendidikan dan jenis kelamin, Tahun 2005,http://www.nakertrans.go.id/pusdatinnaker/BPS/Penganggur/index_ penganggur.php [5 July 2006].

Dimova,Dimo P., Shepherd,Dean A. 2005 “Human capital theory and venture capital firms: exploring "'home runs andstrike outs", Journal of Business Venturing 6 (20): 1-21.

Dolton, P., Vignoles, A., 2000. "The incidence and effects of overeducation in the UK graduate labour market”. Econ. Educ. Rev. 19 (2): 179-198. 
Indeks Modal Manusia... (M. Farid Wajdi)

Evans, D.S., Leighton, L.S., 1989. "Some empirical aspects of entrepreneurship”.American Economic Review. 79 (3): 519-535.

Frese, M., Van Gelderen, M., \& Ombach, M. 2000.”How to plan as a small scale business owner: Psychological process characteristics of action strategies and success". Journal of Small Business Management, 38(2): 1-18.

Garland, J. W., Hoy, F., Boulton, W. R., \& Carland, J. A. (1984).”Differentiating entrepreneurs fromsmall business owners: A conceptualization”.Academy of Management Review, 9(2): 354-359.

Gimeno, J., Folta, T., Cooper, A., Woo, C. 1997. Survival of the fittest?Entrepreneurial human capitaland the persistence of underperforming firms. Adm. SCI. Q. 42 (4): 750-783.

Gomes-Mejia, Luis R., Balkin David B.,Cardy Robert L., 1998, Managing human Resources, Prentice Hall Internationall, New Jersey.

Haber, Sigal., Reichel, Arie. 2006. "The cumulative nature of the entrepreneurial process: The contribution of human capital, planning and environment resources to small venture performance”, Journal of Business Venturing 21(6): 753-772

Hasil Rumusan Panel Diskusi. 2001. Menuju keterbukaan antar wilayah dan daya saing global melalui jaringan bisnis UKM,Pada Acara Peresmian SME Center Di 9 Wilayah Indonesia, Tanggal 7 - 8 Nopember 2001 Hotel Indonesia - Jakarta.

Havnes, Per-Anders., Senneseth, Knut.2001,A panel study of firm growth among SMEs in networks, Kluwer Academic Publishers. Printed In The Netherlands. http://www.Springerlink.Com/Media/ Small Business Economics (16): 293-302.

Hisrich, Robert D., \&Peters, Michael P.1992.Entrepreneurship: Starting, Developing, and Managing a New Enterprise, 2nd Edition, Homewood: BPI/Irwin.

Hitt,M.A. \& Tyler,B.B. 1991, Strategic decision models: "Integrating different perspectives". Strategic Management Journal, (12): 327-351.

Ho, Ngiap Kum., Mula, Joseph. 2001. Impact of advisers on small and medium enterprises' business performance - A Study of CPA interventions on Singaporean Chinese SMEs,working paper, Graduate, International Graduate School of Management, University of South Australia (21 July 2006).

Hudson, Mel., Andi Smart,Mike Bourne, 2001, "Theory and practice in SME performance measurement systems”,MCB University Press, UK, International Journal of Operations \& Production Management, 21 (8): 1096-1115.

Hyrsky, K. 2000. "Entrepreneurial metaphors and concepts: An exploratory study," International Small Business Journal 18(1): 13-34.

Karami, Azhdar., Analoui, Farhad. Kakabadse, Nada Korak. 2006. "The CEOs' characteristics and their strategy development in the UK SME sector", The Journal of Management Development, Proquest Education Journals,25 (3/4): 316-322.

Kuncoro, M. 2000.The economics of industrial agglomeration and clustering, 1976-1996: the case of Indonesia (Java), Unpublished PhD thesis, the University of Melbourne, Melbourne.

Kuratko, Donald F. 2003, Entrepreneurship education: Emerging trends and challenges for the $21^{\text {st }}$ century, Coleman Foundation, White Paper Series For The U.S. Association of Small Business \& Entrepreneurship, The Entrepreneurship Program College of Business Ball State University Muncie, In 47306.

Lee, Kye Woo. 2006. "Effectiveness of government's occupational skills developmentstrategies for smalland medium-scale enterprises:A case study of Korea”, International Journal of Educational Development 26: 278-294

Lundvall, B., Johnson, B. 1994. “The learning economy”.Journalof Industry Studies, 1 (Z2): 23-42.

Mankiw, G., D. Romer \& D. Weil, 1992, “A contribution to the empirics of economic growth”, Quarterly Journal of Economics CVII: 407-437.

Martin, G. \& Staines, H. 1994.”Managerial competences in small firms”. Working Paper Steunpunt OOI: August 200329, Journal ofManagement Development, 13 (7):23-34. 
Mcgregor,Judy. Tweed, David., Pech, Richard. 2004. “Human capital in the new economy: Devil's bargain?”, Journal of Intellectual Capital 5 (1): 153-164. http://www.Emeraldinsight.Com/14691930.Htm.

Mcleish, Anne. 2002. Employability Skills For Australian Small and Medium Sized Enterprises, Employability Skills For The Future Project 2002 Supporting SME Research, Department of Education, Science and Training, Commonwealth of Australia February 2002.

Mile Terziovski, 2003. “The Relationship Between Networking Practices and Business Excellence: A Study of Small To Medium Enterprises (SMEs)”. Measuring Business Excellence.Bradford, 7(2): 78-93.

Morris, M. H. \& D. L. Sexton 1996. “The concept of entrepreneurial intensity: Implications for company performance”. Journal of Business Research.36: 5-13.

Morris, M. H. \& G. Paul 1987. "The relationship between entrepreneurship and marketing in established firms". Journal of Business Venturing.2(3): 247-259.

O’Sullivan, M. 2000. “The sustainability of industrial development in Ireland”, Regional Studies, 34 (3): 277-290.

Pasanen, Mika. 2003. In search of factors affecting SME performance; The case of eastern Finland, Doctoral Dissertation, Faculty of Business and Information Technology of The University 2003, Department of Business and Management University of Kuopio, www.Uku.Fi/Kirjasto/Julkaisutoiminta/Julkmyyn.Htm. [9 February 2006]

Pennings, J.M., Lee, K., Witteloostuijn, A.v., 1998. "Human capital, social capital, and firm dissolution”.Academy Management Journal, 41: 425-440.

Pritchett, Lant. 1997. “Divergence, big time”. Journal of Economic Perspectives,11(Summer): 3-18.

Rahmah Ismail, Norlinda Tendot Abud Bakar. 2008. Analisis kecekapan teknikal firma melayu dalam sektor pembuatan malaysia, IJMS 15(2): 143-163

Rahmah Ismail.1996, Modal manusia dan perolehan buruh, Siri Teks Ekonomi Dewan, Dewan Bahasa dan Pustaka, Kuala Lumpur.

Sambasivan, M., et al. 2009. Impact of personal qualities and management skills of entrepreneurs on venture performance in Malaysia: Opportunity Recognition Technovation (2009), Doi:10.1016/J.Technovation.2009.04.002.

Skuras, Dimitris , Meccherib, N., Moreirac, M. B., Roselld, J., Stathopouloua,S. 2005. "Entrepreneurial human capital accumulation and the growth of rural businesses: A four-country survey in mountainous and lagging areas of the European Union”, Journal of Rural Studies 21: 67-79.

Small and Medium Enterprise Statistics for the UK 2003, published 26th August 2004, http://www.sbs.gov.uk/sbsgov/action/layer?r.s, [12 February 2006].

Smith,Erica.,\&Comyn, Paul.2003, The development of employability skills in novice workers, Australian National Training Authority, Published By Ncver Abn 87007967 311, Po Box 8288, Station Arcade, Sa 5000, Australia.

Susanne, Buesselmann. 2009. Human capital and economic growth, Dissertation,Wayne State University, 173 Pages; Aat 3366669.

Tambunan, Tulus. 2001.Perkembangan UKM dalam era AFTA: peluang, tantangan, permasalahan dan alternatif solusinya, Yayasan Indonesia Forum - LPFE-UI, Jakarta.

Taylor,Michael.,\& Plummer, Paul. 2003. Promoting Local Economic Growth: The Role of Entrepreneurship and Human Capital, Emerald Group Publishing Limited. ISSN 0040-0912, Education + Training 45 (8/9): 558-563,http://www.Emeraldinsight.Com/0040-0912.Htm. [11 July 2005].

The Concise Encyclopedia of Economics, 2002, Human Capitalby Becker,Library of Economics and Libertyhttp://www.econlib.org/ [8 Ogos 2006]

The Concise Encyclopedia of Economics,2002. Biography of Theodore William Schultz 1902-1998, Library of Economics and Libertyhttp://www.econlib.org. [8 Ogos 2006] 
Indeks Modal Manusia... (M. Farid Wajdi)

Thee, Kian Wie, 2006, Policies for Private Sector Development in Indonesia; SME Promotion Policies for Indonesia , ADBI, Asian Development Bank, Paper No: 46, Published: 21 March 2006, http://www.ADB.org/adbi/Indonesia.htm. [27 February 2008].

Wayne, S.J., Liden, R.C., Kraimer, M.L., Graf, I.K., 1999. "The role of human capital, motivation and supervisorsponsorship in predicting career success”.Journal Organization Behavior, 20 (5): 577595.

Westhead, P. 1995. "Survival And Employment Growth Contrasts Between Types Of Owner-Managed High Technology Firms”. Entrepreneurship Theory \& Practice, 20 (1): 5-28.

Wijewardena, H., \& Tibbits, G. E. 1999.”Factors contributing to the growth of small manufacturing firms: Data from Australia”, Journal of Small Business Management, 37 (2): 88-96.

Wiklund, J. 1999. "The Sustainability of The Entrepreneurial Orientation-Performance Relationship”,Entrepreneurship Theory and Practice. 24(1): 37-47.

Wing, Clement Chow Kong., Yiu, Michael Fung Ka. 1996. "Firm Dynamic and Industrialization In The Chinese Economy In Transition: Implication For Small Business Policy”, Elsevier Science Inc., 655 Avenue of The Americas,New York, Journal of Business Venturing(11): 489-505.

Wright, P.M., Smart, D.L., McMahan, G.C., 1995.”Matches between human resources and strategy among NCAAbasketball teams”.AcademyManagement Journal, 39: 441-463.

Yan Wang, Yao Yudong. 2003. "Sources of China's economic growth 1952-1999: incorporating human capital accumulation, Washington, DC 20433, USA”, China Economic Review, 14: 32-52. 